\title{
Prediction of Composition of Broiler Chicken Excreta Using Near-infrared Reflectance Spectroscopy
}

\author{
I. T. Kadim*, W. Al-Marzooqi, O. Mahgoub and K. Annamalai \\ Department of Animal and Veterinary Sciences, College of Agricultural and Marine \\ Sciences, Sultan Qaboos University, PO Box 34, Al-Khod, PC 123, \\ Muscat, Sultanate of Oman
}

\author{
التنبؤ بالمكونات الكيميائية لفضلات الدواجن بأستخدام جهاز معامل الانعكاس بالاشعة تحت الحمراء \\ عصام توفيق كاظم
}

الخلاصة: تم تطوير معايير جعاز معامل الانعكاس بالأشعة تحت الحمراء باستخدام المطياف للتنبؤ بمحتوى المادة الجافة

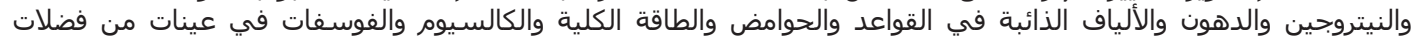

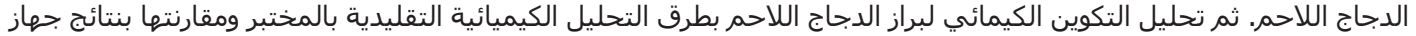

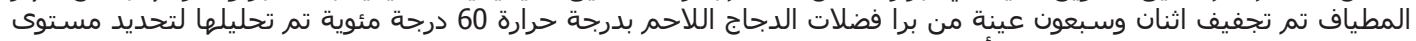

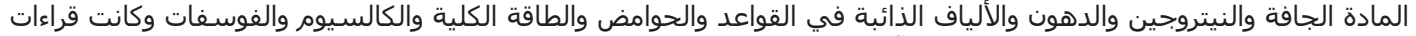
المتوسط العام ومعامل الإنحراف القياسي كالآتي :للمادة الجافة

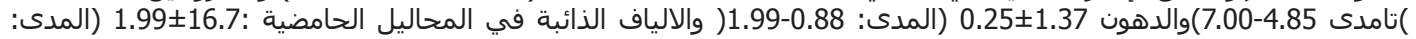

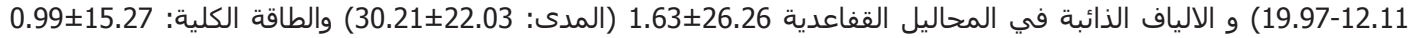

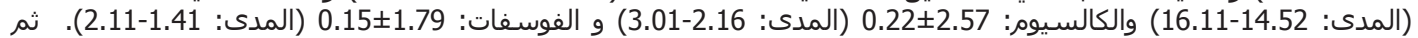

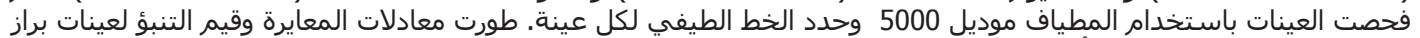

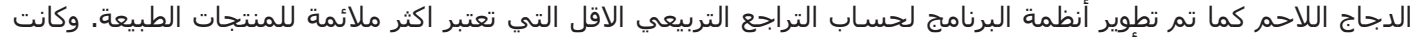

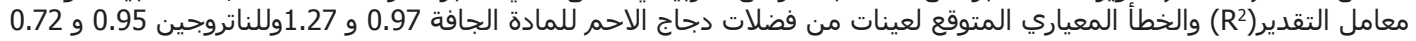

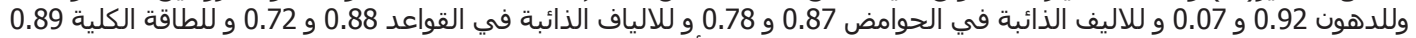
و 0.24 و للكاسيوم 0.96 و 0.06 و للفسففور 0.93 و 0.09 باتتابع. أشارت نتائج هذا البحث إلى امكانية استخدام معيار المطياف للتنبؤ بمكونات فضلات الدجاج اللاحم.

ABSTRACT: Near-infrared reflectance spectroscopic (NIRS) calibrations were developed for the prediction of the content of dry matter (DM); nitrogen (N), ether extract (EE), neutral detergent fibre (NDF), acid detergent fibre (ADF), gross energy (GE), calcium (Ca) and phosphate $(\mathrm{P})$ in broiler excreta samples. The chemical composition of broiler excreta was determined by the conventional chemical analysis methods in the laboratory and compared with NIRS. Excreta samples $(n=72)$ were oven dried $\left(60^{\circ} \mathrm{C}\right)$ and analyzed for $\mathrm{DM}, \mathrm{N}, \mathrm{EE}, \mathrm{NDF}, \mathrm{ADF}, \mathrm{GE}, \mathrm{Ca}$ and $\mathrm{P}$. The determined values (mean $\pm \mathrm{SD}$ ) were as follows: $\mathrm{DM}$ : $31.46 \pm 7.65$ (range: $19.14-44.51$ ), N: $5.85 \pm 2.88$ (range: 4.85 -7.00), EE: $1.37 \pm 0.25$ (range: $0.88-1.99$ ), ADF: $16.71 \pm 1.99$ (range: 12.11-19.97), NDF: $26.26 \pm 1.63$ (range: 22.03-30.21), GE: $15.27 \pm 0.33$ (range: 14.52-16.11), Ca: $2.57 \pm 0.22$ (range: 2.16-3.01), P: $1.79 \pm 0.15$ (range: 1.41-2.11). The samples were then scanned in a NIRS model 5000 analyzer and the spectra obtained for each sample. Calibration equations and prediction values were developed for broiler excreta samples. The software used modified partial least square regression statistic, as it is most suitable for natural products. For broiler excreta samples, the coefficient of determination $\left(\mathrm{R}^{2}\right)$ and the standard error of prediction (SEP) was $\mathrm{DM}=0.97,1.27, \mathrm{~N}=0.95,0.72, \mathrm{EE}=0.92$, $0.07, \mathrm{ADF}=0.87,0.78, \mathrm{NDF}=0.88,0.72, \mathrm{GE}=0.89 ; 0.24, \mathrm{Ca}=0.96,0.06, \mathrm{P}=0.93,0.09$, respectively. The results indicate that it is possible to calibrate NIRS to predict major constituents in broiler excreta samples.

Keywords: Spectroscopy, broiler, excreta, calibration, Oman.

\section{Introduction}

Poultry manure, which is a pollutant in soil and water, is produced in large quantities by the poultry industry. An accurate and fast analytical procedure to detect poultry manure components is becoming more critical in areas with intensive poultry production (Reeves, 2001). In some countries, restrictive manure management guidelines have been adopted, which

\footnotetext{
$\overline{* \text { Corresponding author }}$
} 
need a quick, easy and reliable method for determining excreta composition to assist those abiding by and enforcing regulations. To manage these pressures, it is necessary to collect as much information as possible on raw materials, which depend on analytical laboratory techniques. Traditionally, chemical reference methods are laborious, time consuming and generate hazardous wastes.

Near-infrared reflectance spectroscopy (NIRS) has been widely used as a rapid and accurate method for measuring some constituents of materials without requiring extensive sample preparation (Norris et al., 1976). Components successfully measured include nitrogen, moisture, fibre, starch, individual sugar, amino acids, and fat (Foley et al., 1998; Fontaine et al., 2002; Smith et al., 2001; Valdes and Summers, 1986), The principle of NIRS is the selective absorption of electromagnetic radiation from 800 to 2500 $\mathrm{nm}$ in accordance with the characteristic vibration frequencies of functional groups (De Boever et al., 1994). It has the capability to measure $\mathrm{CH}, \mathrm{NH}, \mathrm{OH}$ bonds, which form the functional groups in moisture, protein, amino acids, fibre, sugar and fat in biological samples. Although organic complexes may be detected (Shenk et al., 1992), no absorption bands for minerals exist in the near-infrared region. Every biological substance has a unique NIRS composite spectrum, depending on their characteristic functional groups; the NIRS spectrum of a sample is the composition of all the physical and chemical information of the sample (De Boever et al., 1994; Murray and Williams, 1987).
The objectives of the current study were to calibrate NIRS spectrometer equations and to evaluate their accuracy to predict chemical composition, moisture, nitrogen, ether extract, neutral detergent fibre, acid detergent fibre, gross energy, calcium and phosphorus in broiler excreta.

\section{Materials and Methods}

Seventy-two broiler excreta samples (500 g) were randomly collected from a broiler feed evaluation project. The excreta samples were dried in a forced air oven at $60^{\circ} \mathrm{C}$ until no decrease in weight occurred. All samples were then left on the laboratory bench for over $48 \mathrm{~h}$ to equilibrate with atmospheric moisture. The samples were ground in a Cyclotech 1093 sample mill with a $0.5-\mathrm{mm}$ screen and were stored in plastic bags until analysis.

\section{Laboratory analysis}

Excreta samples were analysed for dry matter (DM) by drying in an oven at $60{ }^{\circ} \mathrm{C}$ until no decrease in weight occurred, and for organic matter (OM) and ash by ashing dry samples at $450{ }^{\circ} \mathrm{C}$ for $12 \mathrm{~h}$ in a muffle furnace (AOAC, 1990). Triplicate samples of approximately $2 \mathrm{~g}$ each were freeze-dried for 4 days for ether extraction (EE) by petroleum ether in a Soxhlet apparatus. Nitrogen $(\mathrm{N})$ was determined by the Kjeldahl method. Neutral detergent fibre (NDF) was determined by using sodium sulphite and sodium lauryl sulphate as a neutral detergent extracting solution as described by Van Soest et al. (1991). Acid detergent fibre (ADF) was determined using

Table 1. Values for chemical analysis in 72 broiler excreta samples used for the near-infrared reflectance equation .and validation.

\begin{tabular}{lrrrrrrr}
\hline Variable & Mean & SD & Range & SEC & SECV & R $^{2}$ & 1-VR \\
\hline Dry matter (\%) & 31.46 & 7.65 & $19.14-44.51$ & 1.18 & 1.27 & 0.97 & 0.97 \\
Nitrogen (\%) & 5.85 & 2.88 & $4.85-7.00$ & 0.64 & 0.72 & 0.95 & 0.93 \\
Ether extract (\%) & 1.38 & 0.25 & $0.88-1.99$ & 0.07 & 0.07 & 0.92 & 0.91 \\
Acid detergent fibre (\%) & 16.72 & 1.99 & $12.11-19.97$ & 0.71 & 0.78 & 0.87 & 0.85 \\
Neutral detergent fibre (\%) & 26.26 & 1.63 & $22.03-30.21$ & 0.55 & 0.72 & 0.88 & 0.81 \\
Gross energy (MJ/kg) & 15.27 & 0.33 & $14.52-16.11$ & 0.22 & 0.24 & 0.89 & 0.47 \\
Calcium (\%) & 2.57 & 0.22 & $2.16-3.01$ & 0.04 & 0.06 & 0.96 & 0.92 \\
Phosphorous (\%) & 1.79 & 0.15 & $1.41-2.11$ & 0.08 & 0.09 & 0.93 & 0.61 \\
\hline
\end{tabular}

SD: Standard Deviation, SEC: Standard Error of Calibration, SECV: Standard Error of Cross Validation, $\mathrm{R}^{2}$ : coefficient of determination, 1-VR: 1- Variance Ratio. 
Table 2. Near-infrared transmission calibration and validation statistics for broiler excreta.

\begin{tabular}{lrrrrrrr}
\hline Variable & Mean & SD & Range & SEP & Bias & $\mathbf{R}^{\mathbf{2}}$ & Slope \\
\hline Dry matter (\%) & 31.20 & 7.44 & $20.93-42.81$ & 1.56 & 0.188 & 0.96 & 1.01 \\
Nitrogen (\%) & 5.97 & 2.59 & $5.22-6.80$ & 0.77 & 0.125 & 0.93 & 1.04 \\
Ether extract (\%) & 1.38 & 0.27 & $0.86-1.91$ & 0.10 & 0 & 0.88 & 1.01 \\
Acid detergent fibre (\%) & 17.20 & 1.41 & $14.06-19.32$ & 1.07 & 0.053 & 0.65 & 1.05 \\
Neutral detergent fibre (\%) & 26.50 & 1.47 & $22.37-29.51$ & 0.83 & 0.048 & 0.73 & 0.94 \\
Gross energy (MJ/kg) & 15.20 & 0.22 & $14.77-15.63$ & 0.31 & 0.043 & 0.85 & 0.99 \\
Calcium (\%) & 2.57 & 0.19 & $2.22-2.97$ & 0.07 & 0.004 & 0.89 & 0.97 \\
Phosphorous (\%) & 1.79 & 0.11 & $1.52-2.01$ & 0.11 & 0.023 & 0.91 & 0.82 \\
\hline
\end{tabular}

SEP: Standard Error of Prediction.

cetyl trimethyl ammonium bromide and $1 \mathrm{~N}_{2} \mathrm{SO}_{4}$ as described by Roberston and Van Soest (1981). Calcium $(\mathrm{Ca})$ and phosphorus $(\mathrm{P})$ were measured with an atomic absorption spectrophotometer (PHILIPS model PU9100, single beam) according the procedures of AOAC (1990). Gross energy (GE) was measured using a bomb calorimeter. Analysis for all items was done in triplicate on a dry matter basis.

\section{Near-infrared reflectance spectroscopy analysis}

Samples were divided into calibration and prediction sets, which consisted of 72 and 40 samples, respectively. Prediction samples were randomly selected from the calibration samples. All calibration samples were analysed by conventional chemical methods in the laboratory and then scanned in the NIRS for comparison.

A feed and Forage Foss NIRS systems Model 5000 Reflectance Transport Model Analyzer was used for scanning samples and collecting spectra. The software used was WinISI II version 1.50. Interpretation of NIRS spectra was done by calibrating with reference values obtained from laboratory analysis of the sample and correlating them to NIRS measurements of these samples. The reference laboratory data and the sample spectra were used to develop predictive equations. Samples were uniformly mixed and loaded in the NIRS sample cups. About 5-6 g of ground sample were placed in sample cup to about $8 \mathrm{~mm}$ depth, then covered to be processed on the holder gently. Consistency in sample preparation and packing is important for accuracy. The NIR spectrum for each sample was recorded as $\log 1 / \mathrm{R}$ (reflectance) for each wavelength in the NIRS range.

\section{Calibration}

The mathematical relationship between chemical reference values and the NIRS spectral data was analysed by linear regression. Calibrations were made using reference values on a dry matter basis, so the NIRS predicted results are also expressed on a dry matter basis. Spectra of 72 broiler excreta samples were collected in the NIRS region $(800-2800 \mathrm{~nm})$. Calibration equations were computed for DM, N, $\mathrm{EE}, \mathrm{ADF}, \mathrm{NDF}, \mathrm{GE}, \mathrm{Ca}$ and $\mathrm{P}$ using modified partial least squares regression using the WinISI II software. The program calculates the mathematical relationship between the spectral data from the scanned sample and its reference values obtained by standard chemical procedures. The program then calculates the cross validation errors for each component, and the modified partial least square statistics was determined. The program repeats this process for each component and upon completion, the NIRS equation was developed to predict the constituents in the product.

Statistically, the equation was evaluated using the monitor results program, which performs a statistical comparison between chemical reference values and NIRS predicted values for the data set. It also provided tabular and graphical comparison of the two values. Model performance was reported as the coefficient of determination $\left(\mathrm{R}^{2}\right)$, standard error of prediction (SEP), and linear regression of components reference method against predicted values (slope) (Hurschka, 1987).

\section{Results and Discussion}

The descriptive statistics for the different constituents of broiler excreta are summarized in Tables 1 and 2 . There was a considerable variation in the composition, 


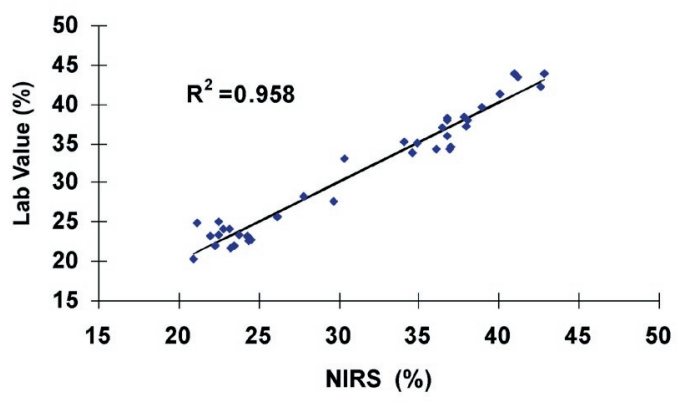

Figure 1. The relationship between near-infrared reflectance spectroscopy (NIRS) predictions and determined percentage dry matter values of 72 broiler excreta samples.

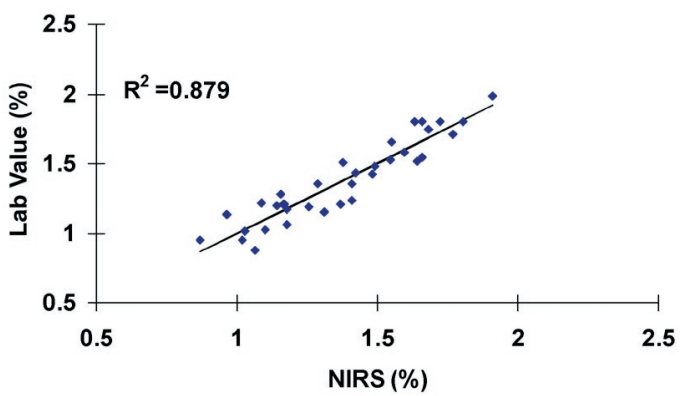

Figure 3. The relationship between near-infrared reflectance spectroscopy (NIRS) predictions and determined fat values (\%) of 72 broiler excreta samples.

as shown by the wide range of values. It is essential for any calibration procedure to ensure that a range of spectral variation found in the whole population is represented in the samples selected for calibration development (Foley et al., 1998). Calibration and validation statistics are shown in Tables 1 and 2, respectively. The range of excreta parameters of DM, $\mathrm{N}, \mathrm{EE}, \mathrm{NDF}, \mathrm{ADF}, \mathrm{GE}, \mathrm{Ca}$ and $\mathrm{P}$ in the calibration set are similar to the corresponding ranges in the prediction set.

Limited studies have been conducted utilizing NIRS to analyse the chemical composition of poultry manure or excreta (Reeves, 2001; Smith et al., 2001). Contradictory conclusions have been reported by these authors on the suitability of the NIRS to estimate the mineral contents. The findings of Reeves

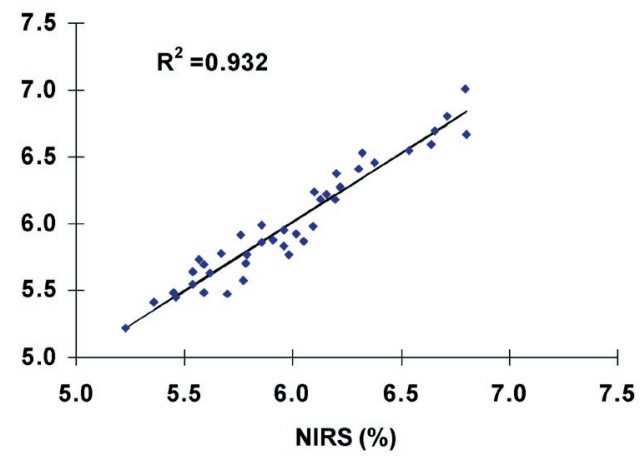

Figure 2. The relationship between near-infrared reflectance spectroscopy (NIRS) predictions and determined nitrogen values (\%) of 72 broiler excreta samples.

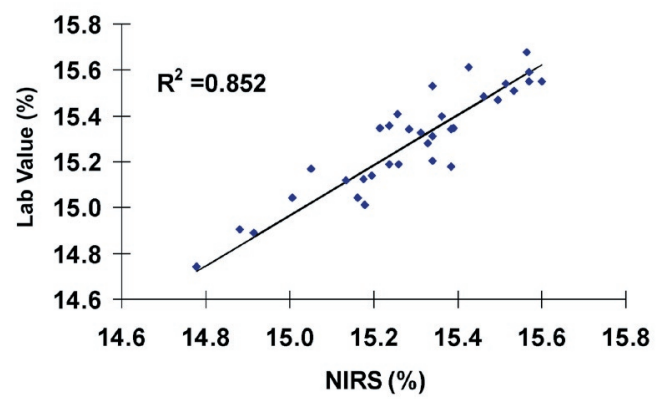

Figure 4. The relationship between near-infrared reflectance spectroscopy (NIRS) predictions and determined gross energy values (\%) of 72 broiler excreta samples.

(2001) indicated that NIRS was not suitable for the determination of minerals ( $\mathrm{P}, \mathrm{Ca}$, etc.) in poultry manure. This may be attributed to the nature of the samples being used. However, Smith et al. (2001) attempted to calibrate an NIRS to predict the $\mathrm{Ca}$ and $\mathrm{P}$ contents of chicken excreta. They obtained an $\mathrm{R}^{2}$ of 0.86 , an SEP of 0.14 for $\mathrm{Ca}$ and $\mathrm{R}^{2} 0.93$ and an SEP of 0.13 for P. They concluded that NIRS was a good predictor for $\mathrm{Ca}$ and total $\mathrm{P}$ content of chick excreta. There are no absorption bands for minerals in the near-infrared region, but organic complexes and chelates may still be detected (De Boever et al., 1994). Studies have shown that $\mathrm{Ca}$ and $\mathrm{P}$ may exist in forms detectable by NIRS, at least in some grasses and legumes (Clark et al., 1987; Saiga et al., 1989). The calibration values obtained for $\mathrm{P}$ in forages were 


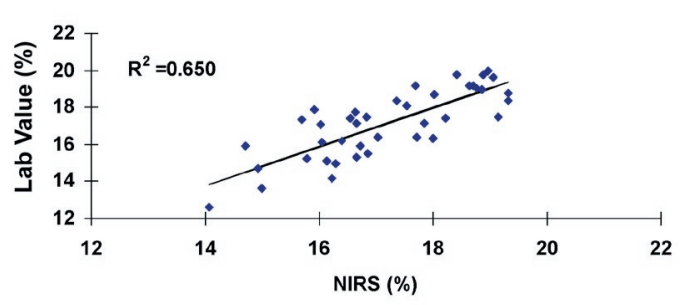

Figure 5. The relationship between near-infrared reflectance spectroscopy (NIRS) predictions and determined acid detergent fibre values (\%) of 72 broiler excreta samples.

found to be acceptable by Clark et al. (1987) but were not acceptable in similar studies by Vasquez Aldana et al. (1995). De Boever et al. (1994) reported that $\mathrm{P}$ of feedstuffs could be predicted by NIRS with an $\mathrm{R}^{2}$ of 0.94 to 0.96 and SEP of 0.08 . In grass samples, Dealdana et al. (1995) found that Ca could be predicted with an $\mathrm{R}^{2} 0.73$ to 0.92 and an SEP 0.15 to 0.22 . The estimation of mineral elements by NIRS is generally dependent on the occurrence of these elements in organic or hydrated molecules (Clark et al., 1987; Vasquez de Aldana et al., 1995), or mineral levels may simply be correlated to some organic material that the NIRS can easily measure. The findings of the present study confirm previous reports that NIRS is a good predictor for $\mathrm{Ca}$ and $\mathrm{P}$ with an $\mathrm{R}^{2}$ of 0.89 and 0.91 , respectively.

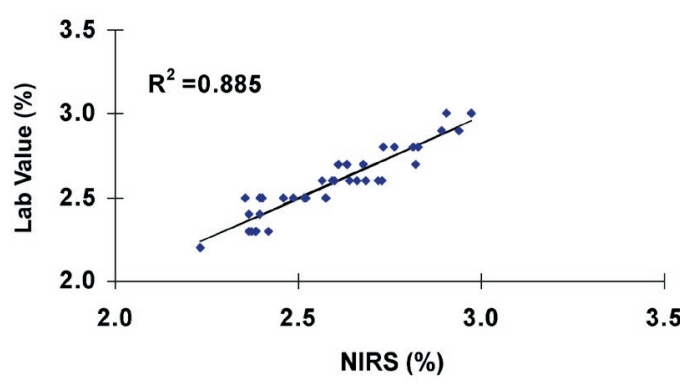

Figure 7. The relationship between near-infrared reflectance spectroscopy (NIRS) predictions and determined calcium values (\%) of 72 broiler excreta samples.

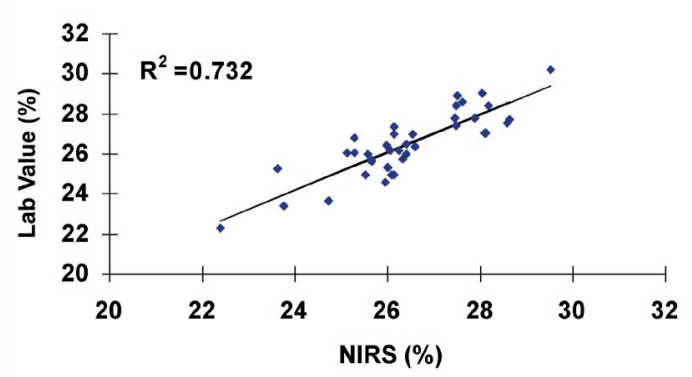

Figure 6. The relationship between near-infrared reflectance spectroscopy (NIRS) predictions and determined neutral detergent fibre values (\%) of 72 broiler excreta samples.

Similarly, high coefficients of determination and relatively low SEP were obtained in the present study for $\mathrm{DM}\left(\mathrm{R}^{2}, 0.96\right.$, SEP, 1.56) (Figure 1), N ( $\mathrm{R}^{2}, 0.93$, SEP, 0.77) (Figure 2), fat ( $\mathrm{R}^{2}, 0.88$, SEP, 0.10) (Figure 3), GE $\left(\mathrm{R}^{2}, 0.85\right.$, SEP, 0.31) (Figure 4), ADF $\left(\mathrm{R}^{2}\right.$, 0.65 , SEP, 1.07) (Figure 5), NDF ( $\mathrm{R}^{2}, 0.73$, SEP, 0.83) (Figure 6), $\mathrm{Ca}\left(\mathrm{R}^{2}, 0.89, \mathrm{SEP}, 0.07\right)$ (Figure 7) and $\mathrm{P}$ $\left(\mathrm{R}^{2}, 0.91\right.$, SEP, 0.11) (Figure 8).

There have been some studies utilizing NIRS to analyse the moisture and $\mathrm{N}$ content of excreta samples. Smith et al. (1999) reported an $\mathrm{R}^{2}$ of 0.97 with an SEP of 0.91 for determining the $\mathrm{N}$ content of rooster excreta and an $\mathrm{R}^{2}$ of 0.92 with an SEP of 0.13 for GE determination. Smith et al. (2001) reported an $\mathrm{R}^{2}$ of 0.93 with an SEP of 0.34 for moisture and an $\mathrm{R}^{2}$

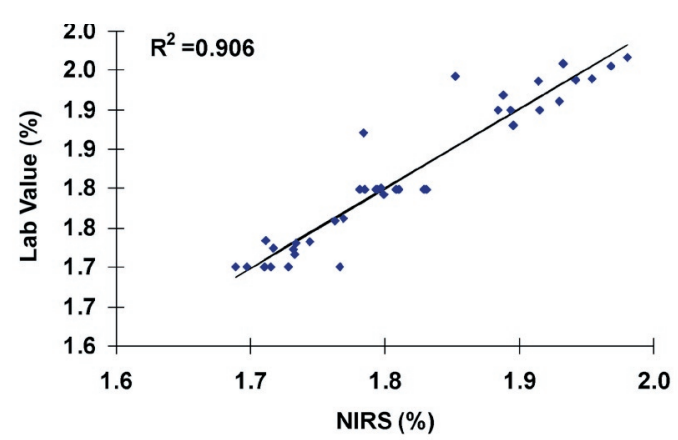

Figure 8. The relationship between near-infrared reflectance spectroscopy (NIRS) predictions and determined phosphorous values (\%) of 72 broiler excreta samples. 
of 0.99 with an SEP of 0.19 for $\mathrm{N}$ contents of chicken excreta, thus supporting the findings of the present study.

\section{Conclusions}

The current study has indicated that determination of the composition of broiler excreta by NIRS is feasible with high accuracy. Therefore, NIRS may be routinely used to predict excreta constituents. It may also be useful in monitoring environmental contamination by the poultry industry. With the inclusion of more samples in the calibration set to cover a broader range of constituents as well as some more refinement in the sampling technique, it would likely seem that more robust calibrations could be developed.

NIRS requires no consumables, it is environment friendly, has no operational cost, needs no sample preparation (only drying and grinding to uniform size) and is cost effective and reproducible. Once the initial calibration and equation model for the excreta sample has been established, NIRS may be used to replace wet chemistry in quantifying many compositional parameters of poultry excreta samples to an acceptable level of accuracy,.

\section{References}

AOAC. 1990. Official Methods for Analysis, $15^{\text {th }}$ ed. Association of Official Analytical Chemists, Arlington, VA, pp 69-90.

Clark, D.H., M.H. Ralphs and R.C. Lamb. 1987. Total alkaloid determinations in larkspur and lupine with near infrared reflectance spectroscopy. Agronomy Journal 79:481-285.

Dealdana, B.R., B.G. Criado, A.G. Cuidad and M.E. Corona. 1995. Estimation of mineral-content in natural grasslands by near-infrared reflectance spectroscopy. Communications in Soil Science and Plant Analysis 26:1238-1396.

De Boever, J.L., W. Eeckhout and C.V. Boucque. 1994. The possibilities of near -infrared reflection spectroscopy to predict total phosphorus, phytate phosphorus and phytase activity in vegetable feedstuff. Netherlands Journal of Agriculture Science 42:357-361.

Foley, W.J., A. Mcllwee, I. Lawler, L. Aragones, A.P. Woolnough and N. Berdig. 1998. Ecological applications of near infrared reflectance spectroscopy: a tool for rapid, cost-effective prediction of the composition of plant and animal tissues and aspects of animal performance. Oecologia 116:293-305.

Fontaine, J., B. Schirmer and J. Horr. 2002. Nearinfrared reflectance spectroscopy (NIRS) enables the fast and accurate prediction of essential amino avid contents. 2. Results for wheat, barely, corn, tricale, wheat bran/middlings, rice bran and sorghum. Journal of Agricultural Food Chemistry 50:3902-3911.

Hurschka, E.R. 1987. Data analysis: Wavelength selection methods. In: Near-Infrared Technology in the Agricultural and Food Industries, P.C. Williams and K.H. Norris (Editors), 35-53, Association of Cereal Chemistry, St. Paul, MN.

Murray, I. and P.C. Williams. 1987. Chemical Principles of Near-infrared Technology. In: Nearinfrared Technology in the Agricultural and Food industries, P. William and K. Norris (Editors), 1734. American Association of Cereal Chemists, St. Paul, MN, USA.

Norris, K.H., R.F. Barnes, J.E. Moore and J.S. Shenk. 1976. Predicting forage quality by near-infrared reflectance spectroscopy. Journal of Animal Science 43:889-897.

Reeves, J.B. 2001. Near-infrared diffuse reflectance spectroscopy for the analysis of poultry manures. Journal of Agricultural and Food Chemistry 49: 2193-2197.

Roberston, J.B. and P.J. Van Soest. 1981. The Detergent System of Analysis. In: The Analysis of Dietary Fibre in Food, W.P.T. James and O. Theander (Editors), 123-158. Marcel Dekker, NY, USA.

Saiga, S., T. Sasaki, K. Nonaka, K. Takahashi, M. Watanabe and K. Watanabe. 1989. Prediction of mineral concentrations of orchardgrass (Datylis glomerata L.) with near infrared reflectance spectroscopy. Journal of Japan Society of Grassland Science 35:228-233.

Shenk, J.S., J.J. Workman and M.O. Westerhaus. 1992. Application of NIR Spectroscopy to Agricultural Products. In: Handbook of Near-Infrared Analysis, D.A. Burns and E.W. Ciurczak (Editors), 383-431. Marcel Dekker, NY, USA.

Smith, T.N., G.M. Pesti, R.I. Bakalli, J. Kiburn and H.M. Edwards, Jr. 2001. The use of near-infrared reflectance spectroscopy to predict the moisture, nitrogen, calcium, total phosphorus, gross energy 
and phytate phosphorus contents of broiler excreta. Poultry Science 80:314-319.

Valdes, E.V and J.D. Summers. 1986. Determination of crude protein and fat in carcass and breast muscle samples of poultry by NIR reflectance spectroscopy. Poultry Science 65:485-490.

Van Soest, P.J., J.B. Roberston and B.A. Lewis. 1991. Methods for dietary fibre NDF and non-starch polysaccharides in relation to animal nutrition. Journal of Dairy Science 74:3583-3597.

Vasquez de Aldana, B.R.B., B. Garcia, A. GarciaCriado and M.E. Perez-Corona. 1995. Estimation of mineral content in natural grasslands by near infrared reflectance spectroscopy. Communications in Soil Science and Plant Analysis 26:1383-1396.

Williams, P. and K.H. Norris. 1987. Chemical Principles of NIR Technology. In: NIR Technology in the Agricultural and Food Industries, 17-34. American Association of Cereal Chemists, Inc., St Paul, MN, USA.

Windham, W.R., K.C. Lawrence and P.W. Feldner. 2003. Prediction of fat content in poultry meat by near-infrared transmission analysis. Journal of Applied Poultry Research 12:69-73.

Received: October 2004

Acceptted: October 2005 